УДК 631.53:633.112.9 DOI 10.31210/visnyk2018.03.02

(C) 2018

Шевніков М. Я., доктор сільськогосподарських наук,

Міленко О. Г., кандидат сільськогосподарських наук,

Лотии І. І., кандидат сільськогосподарських наук

Полтавська державна аграрна академія

\title{
УРОЖАЙНІСТЬ СОРТІВ СОЇ ЗАЛЕЖНО ВІД ЕЛЕМЕНТІВ ТЕХНОЛОГІЇ ВИРОЩУВАННЯ
}

\section{Рецензент - доктор сільськогосподарських наук, професор П. В. Писаренко}

Подальше поширення сої стримується недостатньо обгрунтованою зональною технологією іï вирощування. Норма висіву впливала на величину врожайності сої більше, ніж спосіб сівби. Сорт Романтика максимальну врожайність мав за норми висіву 700 тис./га - 2,41 m/га. Занижені норми висіву сприяли зниженню врожайності насіння до 2,07 m/2а за норми висіву 600 тис./га та до 1,82 m/га - за норми 500 тис./га. Збільшення норми висіву до 800 тис./га було неефективним - 2,39 m/2а. У скоростиглого сорту Устя найбільша врожайність була за норми висіву 700 тис./2а - 2,48 m/2а. Занижені норми висіву сприяли зниженню врожайності насіння до 2,11 m/2a - за норми висіву 600 тис./га, до 1,99 m/га - за норми 500 тис./га. Збільшення норми висіву до 800 тис./га не сприяло підвищенню врожайності - 2,35 m/2a. За зрідженого розміщення рослин характерне близьке до поверхні трунту закладання бобів, яке спричиняє значні втрати врожаю під час збирання.

Ключові слова: соя, сорти, строки, способи $i$ норми сівби, урожайність.

Постановка проблеми. Надійним шляхом одержання високоякісних, екологічно безпечних продуктів харчування з насіння сої та зниження собівартості продукції $є$ впровадження у виробництво таких технологій вирощування, які б передбачали високо інтенсивне функціонування симбіотичної системи, фіксацію атмосферного азоту, обмежене застосування пестицидів та мінеральних добрив.

У зв'язку з інтенсифікацією виробництва сої виникає питання з'ясування елементів технології вирощування, які мають забезпечити високу іiі продуктивність. Серед них вирішальне значення мають строки, способи і норми сівби різних сортів сої. Необхідність повернутися до цього питання зумовлена постійною зміною сортів у виробництві та різними грунтово-кліматичними умовами їх вирощування.

Подальше поширення сої в умовах нестійкого зволоження лівобережної частини Лісостепу стримується недостатньо обгрунтованою зональною технологією іiі вирощування, особливо за ранньої сівби, де тепло є обмежуючим фактором, а волога - достатнім.

Аналіз основних досліджень і публікацій, у яких започатковано розв'язання проблеми. Сортові ресурси сої в Україні складаються на $80 \%$ із сортів вітчизняної селекції та на $20 \%$ - із сортів зарубіжної селекції, що дає широкий спектр підбору сортів з урахуванням зони вирощування $[1,5]$. За скоростиглістю виділяють такі групи сортів сої: ультраранні з вегетаційним періодом до 85 днів та нормою висіву 750-850 тис. шт./га; ранньостиглі відповідно 86-105 днів та 650-750 тис. шт./га; середньо ранньостиглі - 106-125 днів та 550-650 тис. шт./га; середньостиглі - 126-135 днів та 450550 тис. шт./га $[4,7]$. Подальше поширення сої в умовах нестійкого зволоження лівобережної частини Лісостепу стримується недостатньо обгрунтованою зональною технологією іiі вирощування, особливо за ранньої сівби, де тепло $є$ обмежуючим фактором. Потребують вивчення процеси формування врожаю і якості насіння сої за різних строків сівби. Вибираючи строк сівби, слід розраховувати на повне використання рослинами вегетаційного періоду, родючості грунту, особливостей вологозабезпечення місцевості, тому що критичний період за водоспоживанням повинен припадати на фазу «цвітіння - формування бобів». Дослідження, проведені в зоні Лісостепу України, вказують, що найбільшу врожайність одержано за сівби в роки 3 ранньою весною наприкінці квітня, в роки з пізньою весною - у першій декаді травня $[1,6]$.

У посівах сої з оптимальною густотою і площею живлення рослин основна кількість бобів формується на головному пагоні, у зріджених - на бокових гілках. Негативна дія надмірного загущення призводить до вилягання, передчасного пожовтіння і опадання листків, неповного використання світла, вологи, поживних речовин, зниження біологічної фіксації азоту з атмосфери [2]. Збільшення норми висіву з 400 до 1200 тис./га рослин призводило до скорочення вегетаційного періоду, значного видовження рослин та зменшення врожайності насіння за рахунок утворення бобів лише у верхній 


\section{СІЛЬСЬКЕ ГОСПОДАРСТВО. РОСЛИННИЦТВО}

частині рослин. У загущених посівах сої боби формувались в центральній і верхній частині стебла, такі рослини швидко скидали листки, спостерігалося інтенсивне полягання та збільшувалися втрати за комбайнового збирання [3]. Залежно від норми висіву соя змінює індивідуальну продуктивність, кількість бобів і насіння, масу насіння, висоту прикріплення нижніх бобів. За умов дотримання оптимальної густоти рослин, основна кількість бобів і насіння (65-75\%) формується на головному стеблі, 25-35\% - на бокових гілках. У конкретних грунтово-кліматичних умовах оптимальною для кожного сорту є така густота рослин, яка забезпечує максимальну фотосинтетичну i симбіотичну їх діяльність та формування високого врожаю насіння [8, 9].

Отже, рівень продуктивності рослин сої значною мірою визначається зміною площі живлення та способами розміщення їх у посіві. У зв'язку з цим вивчення впливу величини та форми площі живлення на конкурентні взаємозв'язки рослин в агробіоценозі та індивідуальну продуктивність рослин сортів сої є важливою науковою проблемою.

Метою досліджень було встановлення оптимальної густоти посіву сої шляхом правильного вибору норми висіву і способу сівби, які б забезпечили оптимальний ріст і розвиток рослин та високу продуктивність.

Методика проведення досліджень. При визначенні строку сівби враховували, що ранній строк відповідає мінімальній температурі грунту $\left(8-10^{\circ} \mathrm{C}\right)$, за якої можливе проростання насіння сої. Оптимальний строк сівби визначали умовою прогрівання грунту до $+12-14{ }^{\circ} \mathrm{C}$. Пізній строк сівби відповідав підвищенню температури грунту до $+16-18{ }^{\circ} \mathrm{C}$. У перших двох випадках обов'язково враховували також достатне вологозабезпечення верхнього шару грунту. Пізній строк сівби частіше супроводжувався низькою вологістю посівного шару грунту.

Результати дослідження. Негативна дія надмірного загущення призводить до вилягання, передчасного пожовтіння i опадання листків, неповного використання світла, вологи, поживних речовин, зниження біологічної фіксації азоту 3 атмосфери. Соя чутлива до зміни величини і форми площі живлення рослин у посіві. Максимальне використання продуктів фотосинтезу у неї припадає на репродуктивну стадію, тому ширина міжрядь і площа живлення рослин має бути такою, щоб рослинний покрив повністю застилав грунтову поверхню до початку цвітіння. У загущеному посіві боби формуються у верхній частині рослин, наслідком цього $є$ низька урожайність насіння.
За зрідженого розміщення рослин характерне близьке до поверхні грунту закладання бобів, яке спричиняє значні втрати врожаю під час збирання.

Норма висіву впливала на величину врожайності сої більше, ніж спосіб сівби (табл. 1).

Підвищення норми висіву до 800 тис./га схожих насінин, особливо за сівби в пізні строки, не сприяло суттєвому підвищенню врожайності. Тому найбільш доцільно сою сіяти звичайним рядковим (15 см) або широкорядним (45 см) способами 3 нормою висіву 700 тис./га схожих насінин.

Ранньостиглий сорт Романтика мав найбільшу врожайність насіння за рядкової сівби з нормою висіву 800 тис./га за другого строку сівби 3,07 т/га (перший строк сівби - 2,38 т/га, третій строк - 2,40 т/га). За широкорядної сівби (45 см) та цієї норми висіву показники врожайності мали відповідне значення - 2,78 т/га $(2,40$ і 2,77 т/га). Зменшення норми висіву насіння за рядкової сівби з 700 до 500 тис./га призвело до зниження врожайності насіння від 5,3 до 19,9 \%, за широкорядної сівби - від 3,0 до 14,4%.

Скоростиглий сорт Устя мав найбільшу врожайність насіння за рядкової сівби з нормою висіву 800 тис./га за другого строку сівби - 2,72 т/га (перший строк сівби - 2,34 т/га, третій строк - 2,31 т/га). За широкорядної сівби (45см) та даною нормою висіву показники врожайності мали відповідне значення - 2,81 т/га (2,53 і 2,38 т/га). Зменшення норми висіву насіння за рядкової сівби з 700 до 500 тис./га призвело до зниження врожайності насіння від 8,1 до 20,2 \%, за широкорядної сівби - від 6,1 до 25,0%.

Скоростиглий сорт Ворскла мав найбільшу врожайність насіння за рядкової сівби 3 нормою висіву 700 тис./га за другого строку сівби - 2,85 т/га (перший строк сівби - 2,25 т/га, третій строк - 2,39 т/га). За широкорядної сівби (45 см) та нормою висіву 800 тис./га показники врожайності мали відповідне значення - 2,77 т/га (2,54 і 2,45 т/га). Зменшення норми висіву насіння за рядкової сівби з 700 до 500 тис./га призвело до Зниження врожайності насіння від 19,0 до 25,7 \%, за широкорядної сівби - від 3,8 до 16,3 \%.

За ранньої сівби соя достигає раніше, але тривалість вегетаційного періоду залишається найдовшою. За пізньої сівби вегетаційний період був скороченим за рахунок прискореної вегетації рослин в процесі росту і розвитку. Слід враховувати, що правильно обраний строк сівби дає можливість рослинам якомога повніше використовувати вегетаційний період, родючість грунту. Найбільша кількість опадів повинна припадати на критичний період водоспоживання. 
СІЛЬСЬКЕ ГОСПОДАРСТВО. РОСЛИННИЦТВО

\section{1. Урожайність насіння соӥ залежно від сорту, норми висіву, строку та способу сівби (середне за 2013-2015 рp.)}

\begin{tabular}{|c|c|c|c|c|c|}
\hline \multirow{2}{*}{$\begin{array}{c}\text { Сорт } \\
\text { (фактор A) }\end{array}$} & \multirow{2}{*}{$\begin{array}{c}\text { Спосіб сівби } \\
\text { (фактор В) }\end{array}$} & \multirow{2}{*}{$\begin{array}{l}\text { Норма ви- } \\
\text { сіву, тис./га } \\
\text { (фактор С) }\end{array}$} & \multicolumn{3}{|c|}{ Урожайність, т/га } \\
\hline & & & $\begin{array}{c}\text { перший } \\
\text { строк сівби }\end{array}$ & $\begin{array}{c}\text { другий } \\
\text { строк сівби }\end{array}$ & $\begin{array}{c}\text { третій } \\
\text { строк сівби }\end{array}$ \\
\hline \multirow{8}{*}{ Романтика } & \multirow{4}{*}{$\begin{array}{c}\text { рядковий, } \\
15 \text { см }\end{array}$} & 500 & 1,95 & 2,46 & 2,24 \\
\hline & & 600 & 2,20 & 2,88 & 2,35 \\
\hline & & 700 & 2,33 & 2,91 & 2,33 \\
\hline & & 800 & 2,38 & 3,07 & 2,40 \\
\hline & \multirow{4}{*}{$\begin{array}{c}\text { широкорядний, } \\
45 \text { см }\end{array}$} & 500 & 1,68 & 2,38 & 2,05 \\
\hline & & 600 & 1,94 & 2,60 & 2,43 \\
\hline & & 700 & 2,48 & 2,70 & 2,95 \\
\hline & & 800 & 2,40 & 2,78 & 2,77 \\
\hline \multirow{8}{*}{ Устя } & \multirow{4}{*}{$\begin{array}{c}\text { рядковий, } \\
15 \text { см }\end{array}$} & 500 & 1,61 & 2,17 & 1,82 \\
\hline & & 600 & 2,16 & 2,29 & 1,94 \\
\hline & & 700 & 2,16 & 2,50 & 2,21 \\
\hline & & 800 & 2,34 & 2,72 & 2,31 \\
\hline & \multirow{4}{*}{$\begin{array}{c}\text { широкорядний, } \\
45 \text { см }\end{array}$} & 500 & 2,04 & 2,11 & 2,16 \\
\hline & & 600 & 2,30 & 2,25 & 2,28 \\
\hline & & 700 & 2,45 & 2,64 & 2,75 \\
\hline & & 800 & 2,53 & 2,81 & 2,38 \\
\hline \multirow{8}{*}{ Ворскла } & \multirow{4}{*}{$\begin{array}{c}\text { рядковий, } \\
15 \mathrm{~cm}\end{array}$} & 500 & 1,73 & 2,12 & 1,90 \\
\hline & & 600 & 1,81 & 2,31 & 2,28 \\
\hline & & 700 & 2,25 & 2,85 & 2,39 \\
\hline & & 800 & 2,16 & 2,75 & 2,47 \\
\hline & \multirow{4}{*}{$\begin{array}{c}\text { широкорядний, } \\
45 \text { см }\end{array}$} & 500 & 1,75 & 2,32 & 1,89 \\
\hline & & 600 & 2,07 & 2,48 & 2,21 \\
\hline & & 700 & 2,40 & 2,60 & 2,65 \\
\hline & & 800 & 2,54 & 2,77 & 2,45 \\
\hline
\end{tabular}

$\mathrm{HIP}_{05, \text { т/га }}$ для фактору: $\mathrm{A}-0,07 ; \mathrm{B}-0,08 ; \mathrm{C}-0,06 ; \mathrm{ABC}-0,10$

Особливості формування врожаю за різних строків сівби вплинули на продуктивність сої. Важливим показником, що визначає майбутню урожайність, є польова схожість насіння. Враховуючи, що насіння мало однакову лабораторну схожість, польова схожість була більшою за раннього $(64,8 \%)$ та оптимального $(63,9 \%)$ строків сівби. За пізньої сівби польова схожість знизилася до 59,7\%, що пояснюємо умовами недостатнього зволоження верхнього шару грунту. Дослідженнями встановлено, що за пізніх строків сівби сої у верхньому шарі грунту спостерігався дефіцит вологи, сходи були недружні, дещо ослаблені й густота рослин під час збирання на цих ділянках виявилась на 10-15\% меншою, ніж за сівби в оптимальний строк. Урожайність насіння сої першого строку сівби залежно від сортів, способів сівби та норм висіву наведено в таблиці 2. Серед сортів сої найбільша врожайність насіння була у скоростиглого сорту Устя (2,21 т/га) і ранньостиглого сорту Романти- ка $(2,17$ т/га), дещо нижча - у скоростиглого сорту Ворскла (2,09 т/га). Аналіз врожайності сої за способами сівби показав, що за рядкового способу сівби найбільшою вона була у ранньостиглого сорту Романтика (2,22 т/га) (широкорядний спосіб сівби, $45 \mathrm{~cm}-2,13$ т/га). Скоростиглі сорти Устя і Ворскла мали іншу залежність від цього показника - більшою врожайність була за широкорядного способу сівби і становила, відповідно, 2,33 і 2,19 т/га. За рядкової сівби вона знижувалася до 2,09 т/га у сорту Устя та до 1,99 т/га - у сорту Ворскла.

Аналіз урожайності сої сортів залежно від норми сівби за різної скоростиглості показав деякі відмінності. Ранньостиглий сорт Романтика максимальну врожайність мав за норми висіву 700 тис./га - 2,41 т/га. Занижені норми висіву сприяли зниженню врожайності насіння до 2,07 т/га - за норми висіву 600 тис./га та до 1,82 т/га - за норми 500 тис./га. Збілышення норми висіву до 800 тис./га також було менш ефективним - 2,39 т/га. 


\section{2. Урожайність насіння сої першого строку сівби залежно від сортів, способів сівби та норм висіву (середнє за 2013-2015 рр.)}

\begin{tabular}{|c|c|c|c|c|c|c|}
\hline \multirow{2}{*}{$\begin{array}{c}\text { Сорт } \\
\text { (фактор A) }\end{array}$} & \multirow{2}{*}{$\begin{array}{c}\text { Спосіб сівби } \\
\text { (фактор В) }\end{array}$} & \multirow{2}{*}{$\begin{array}{l}\text { Норма висі- } \\
\text { ву, тис./га } \\
\text { (фактор С) }\end{array}$} & \multirow{2}{*}{$\begin{array}{l}\text { Урожай- } \\
\text { ність, } \\
\text { т/га }\end{array}$} & \multicolumn{3}{|c|}{ Середнє за фактором } \\
\hline & & & & A & B & $\mathrm{C}$ \\
\hline \multirow{8}{*}{ Романтика } & \multirow{4}{*}{$\begin{array}{c}\text { рядковий, } \\
15 \text { см }\end{array}$} & 500 & 1,95 & \multirow{8}{*}{2,17} & \multirow{4}{*}{2,22} & 1,82 \\
\hline & & 600 & 2,20 & & & 2,07 \\
\hline & & 700 & 2,33 & & & 2,41 \\
\hline & & 800 & 2,38 & & & 2,39 \\
\hline & \multirow{4}{*}{$\begin{array}{c}\text { широкорядний, } \\
45 \text { см }\end{array}$} & 500 & 1,68 & & \multirow{4}{*}{2,13} & \\
\hline & & 600 & 1,94 & & & \\
\hline & & 700 & 2,48 & & & \\
\hline & & 800 & 2,40 & & & \\
\hline \multirow{8}{*}{ Устя } & \multirow{4}{*}{$\begin{array}{c}\text { рядковий, } \\
15 \mathrm{~cm}\end{array}$} & 500 & 1,61 & \multirow{8}{*}{2,21} & \multirow{4}{*}{2,09} & 1,67 \\
\hline & & 600 & 2,16 & & & 1,99 \\
\hline & & 700 & 2,26 & & & 2,36 \\
\hline & & 800 & 2,34 & & & 2,44 \\
\hline & \multirow{4}{*}{$\begin{array}{c}\text { широкорядний, } \\
45 \text { см }\end{array}$} & 500 & 2,04 & & \multirow{4}{*}{2,33} & \\
\hline & & 600 & 2,30 & & & \\
\hline & & 700 & 2,45 & & & \\
\hline & & 800 & 2,53 & & & \\
\hline \multirow{8}{*}{ Ворскла } & \multirow{4}{*}{$\begin{array}{c}\text { рядковий, } \\
15 \text { см }\end{array}$} & 500 & 1,73 & & \multirow{4}{*}{1,99} & 1,74 \\
\hline & & 600 & 1,81 & & & 1,94 \\
\hline & & 700 & 2,25 & & & 2,33 \\
\hline & & 800 & 2,16 & & & 2,35 \\
\hline & \multirow{4}{*}{$\begin{array}{c}\text { широкорядний, } \\
45 \mathrm{~cm}\end{array}$} & 500 & 1,75 & 2,09 & \multirow{4}{*}{2,19} & \\
\hline & & 600 & 2,07 & & & \\
\hline & & 700 & 2,40 & & & \\
\hline & & 800 & 2,54 & & & \\
\hline
\end{tabular}

$\mathrm{HIP}_{05, \mathrm{~T} / \text { ra }}$ для фактору: $\mathrm{A}-0,07 ; \mathrm{B}-0,08 ; \mathrm{C}-0,06 ; \mathrm{ABC}-0,10$

У скоростиглого сорту Устя найбільша врожайність була за норми висіву 800 тис./га - 2,44 т/га. Занижені норми висіву сприяли зниженню врожайності насіння до 2,36 т/га - за норми висіву 700 тис./га, до 1,99 т/га - за норми 600 тис./га та до 1,67 т/га - за норми висіву 500 тис./га. Скоростиглий сорт Устя найбільшу врожайність також мав за норми висіву 800 тис./га - 2,35 т/га. Занижені норми висіву сприяли зниженню врожайності насіння до 2,33 т/га - за норми висіву 700 тис./га, до 1,94 т/га - за норми 600 тис./га та до 1,74 т/га - за норми висіву 500 тис./га.

Серед сортів сої найбільша врожайність насіння була у ранньостиглого сорту Романтика - 2,74 т/га. У скоростиглого сорту Ворскла - 2,52 т/га, дещо нижча - у скоростиглого сорту Устя - 2,42 т/га (табл. 3). Аналіз врожайності сої за способами сівби показав, що за рядкового способу сівби найбільшою вона була також у ранньостиглого сорту Романтика - 2,86 т/га (широкорядний спосіб сівби,
45 см - 2,61 т/га). Скоростиглі сорти Устя і Ворскла мали іншу залежність від цього показника - їхня врожайність не залежала, за нашими даними, від способу сівби, а визначалася лише сортовими особливостями: у сорту Устя - 2,42-2,43 т/га, у сорту Ворскла - 2,51-2,54 т/га.

Аналіз урожайності сої сортів залежно від норми сівби за різної скоростиглості мав також деякі відмінності. Ранньостиглий сорт Романтика максимальну врожайність мав за норми висіву 800 тис./га - 2,88 т/га. Занижені норми висіву сприяли зниженню врожайності насіння до $2,81 \mathrm{~T} /$ га - за норми висіву 700 тис./га, до 2,74 т/га - за норми 600 тис./га та до 2,42 - за норми 500 тис./га.

У скоростиглого сорту Устя найбільша врожайність була за норми висіву 800 тис./га - 2,71 т/га. Занижені норми висіву сприяли зниженню врожайності насіння до 2,57 т/га - за норми висіву 700 тис./га, до 2,27 т/га - за норми 600 тис./га та до 2,14 т/га - за норми висіву 500 тис./га. 


\section{СІЛЬСЬКЕ ГОСПОДАРСТВО. РОСЛИННИЦТВО}

Скоростиглий сорт Ворскла найбільшу врожайність також мав за норми висіву 800 тис./га - 2,76 т/га. Занижені норми висіву сприяли зниженню врожайності насіння до 2,73 т/га - за норми висіву 700 тис./га, до 2,40 т/га - за норми 600 тис./га та до $2,22 \mathrm{~T} /$ га - за норми висіву 500 тис./га.

Урожайність насіння сої третього строку сівби залежно від сортів, способів сівби та норм висіву подано в таблиці 4. Серед сортів сої найбільша врожайність насіння була у ранньостиглого сорту Романтика $-2,44$ т/га. У скоростиглого сорту Ворскла $-2,28$ т/га, дещо нижча - у скоростиглого сорту Устя - 2,23 т/га. Аналіз врожайності сої за способами сівби показав, що за широкорядного способу сівби найбільшою вона була також у ранньостиглого сорту Романтика - 2,55 т/га (рядковий спосіб сівби, 15 см - 2,33 т/га). Скоростиглий сорт Ворскла мав іншу залежність від цього показника - його врожайність не залежала від способу сівби, а визначалася лише сортовими особливостями (2,26-2,30 т/га). У скоростиглого сорту Устя урожайність насіння за ряд- кової сівби становила 2,07 т/га, за широкорядної сівби - 2,39 т/га. Аналіз урожайності сої сортів залежно від норми сівби за різної скоростиглості мав також деякі відмінності.

Ранньостиглий сорт Романтика максимальну врожайність мав за норми висіву 700 тис./га - 2,64 т/га. Занижені норми висіву сприяли зниженню врожайності насіння до 2,39 т/га - за норми висіву 600 тис./га, до 2,03 т/га - за норми 500 тис./га. Збільшення норми висіву до 800 тис./га не сприяло підвищенню врожайності - 2,59 т/га.

У скоростиглого сорту Устя найбільша врожайність була за норми висіву 700 тис./га $-2,48$ т/га. Занижені норми висіву сприяли зниженню врожайності насіння до 2,11 т/га - за норми висіву 600 тис./га, до 1,99 т/га - за норми 500 тис./га. Збільшення норми висіву до 800 тис./га не сприяло підвищенню врожайності - 2,35 т/га. Скоростиглий сорт Ворскла найбільшу врожайність також мав за норми висіву 700 тис./га 2,52 т/га.

\section{3. Урожайність насіння сої другого строку сівби залежно від сортів, способів сівби та норм висіву (середнє за 2013-2015 рр.)}

\begin{tabular}{|c|c|c|c|c|c|c|}
\hline \multirow{2}{*}{$\begin{array}{c}\text { Сорт } \\
\text { (фактор A) }\end{array}$} & \multirow{2}{*}{$\begin{array}{c}\text { Спосіб сівби } \\
\text { (фактор В) }\end{array}$} & \multirow{2}{*}{$\begin{array}{l}\text { Норма висі- } \\
\text { ву, тис./га } \\
\text { (фактор С) }\end{array}$} & \multirow{2}{*}{$\begin{array}{c}\text { Урожай- } \\
\text { ність, } \\
\text { т/га }\end{array}$} & \multicolumn{3}{|c|}{ Середнє за фактором } \\
\hline & & & & A & B & $\mathrm{C}$ \\
\hline \multirow{8}{*}{ Романтика } & \multirow{4}{*}{$\begin{array}{c}\text { рядковий, } \\
15 \text { см }\end{array}$} & 500 & 2,46 & \multirow{8}{*}{2,74} & \multirow{4}{*}{2,86} & 2,42 \\
\hline & & 600 & 2,88 & & & 2,74 \\
\hline & & 700 & 2,91 & & & 2,81 \\
\hline & & 800 & 3,07 & & & 2,88 \\
\hline & \multirow{4}{*}{$\begin{array}{c}\text { широкоряд- } \\
\text { ний, } 45 \text { см }\end{array}$} & 500 & 2,38 & & \multirow{4}{*}{2,61} & \\
\hline & & 600 & 2,60 & & & \\
\hline & & 700 & 2,70 & & & \\
\hline & & 800 & 2,78 & & & \\
\hline \multirow{8}{*}{ Устя } & \multirow{4}{*}{$\begin{array}{c}\text { рядковий, } \\
15 \text { см }\end{array}$} & 500 & 2,17 & \multirow{8}{*}{2,42} & \multirow{4}{*}{2,42} & 2,14 \\
\hline & & 600 & 2,29 & & & 2,27 \\
\hline & & 700 & 2,50 & & & 2,57 \\
\hline & & 800 & 2,72 & & & 2,71 \\
\hline & \multirow{4}{*}{$\begin{array}{c}\text { широкоряд- } \\
\text { ний, } 45 \text { см }\end{array}$} & 500 & 2,11 & & \multirow{4}{*}{2,43} & \\
\hline & & 600 & 2,25 & & & \\
\hline & & 700 & 2,64 & & & \\
\hline & & 800 & 2,71 & & & \\
\hline \multirow{8}{*}{ Ворскла } & \multirow{4}{*}{$\begin{array}{c}\text { рядковий, } \\
15 \text { см }\end{array}$} & 500 & 2,12 & \multirow{8}{*}{2,52} & \multirow{4}{*}{2,51} & 2,22 \\
\hline & & 600 & 2,31 & & & 2,40 \\
\hline & & 700 & 2,85 & & & 2,73 \\
\hline & & 800 & 2,75 & & & 2,76 \\
\hline & \multirow{4}{*}{$\begin{array}{c}\text { широкоряд- } \\
\text { ний, } 45 \text { см }\end{array}$} & 500 & 2,32 & & \multirow{4}{*}{2,54} & \\
\hline & & 600 & 2,48 & & & \\
\hline & & 700 & 2,60 & & & \\
\hline & & 800 & 2,77 & & & \\
\hline
\end{tabular}

$\mathrm{HIP}_{05, \mathrm{t} / \mathrm{ra}}$, для фактору: $\mathrm{A}-0,07 ; \mathrm{B}-0,08 ; \mathrm{C}-0,06 ; \mathrm{ABC}-0,10$ 
СІЛЬСЬКЕ ГОСПОДАРСТВО. РОСЛИННИЦТВО

\section{4. Урожайність насіння сої третього строку сівби залежно від сортів, способів сівби} та норм висіву (середнє за 2013-2015 рр.)

\begin{tabular}{|c|c|c|c|c|c|c|}
\hline \multirow{2}{*}{$\begin{array}{c}\text { Сорт } \\
\text { (фактор A) }\end{array}$} & \multirow{2}{*}{$\begin{array}{c}\text { Спосіб сівби } \\
\text { (фактор В) }\end{array}$} & \multirow{2}{*}{$\begin{array}{l}\text { Норма висі- } \\
\text { ву, тис./га } \\
\text { (фактор С) }\end{array}$} & \multirow{2}{*}{$\begin{array}{c}\text { Урожай- } \\
\text { ність, } \\
\text { т/га }\end{array}$} & \multicolumn{3}{|c|}{ Середнє за фактором } \\
\hline & & & & $\mathrm{A}$ & B & $\mathrm{C}$ \\
\hline \multirow{8}{*}{$\begin{array}{c}\text { Ранньостиглий } \\
\text { (с. Романтика) }\end{array}$} & \multirow{4}{*}{$\begin{array}{c}\text { рядковий, } \\
15 \text { см }\end{array}$} & 500 & 2,24 & \multirow{8}{*}{2,44} & \multirow{4}{*}{2,33} & 2,03 \\
\hline & & 600 & 2,35 & & & 2,39 \\
\hline & & 700 & 2,33 & & & 2,64 \\
\hline & & 800 & 2,40 & & & 2,59 \\
\hline & \multirow{4}{*}{$\begin{array}{c}\text { широкоряд- } \\
\text { ний, } 45 \text { см }\end{array}$} & 500 & 2,05 & & \multirow{4}{*}{2,55} & \\
\hline & & 600 & 2,43 & & & \\
\hline & & 700 & 2,95 & & & \\
\hline & & 800 & 2,77 & & & \\
\hline \multirow{8}{*}{$\begin{array}{c}\text { Скоростиглий } \\
\text { (с. Устя) }\end{array}$} & \multirow{4}{*}{$\begin{array}{c}\text { рядковий, } \\
15 \text { см }\end{array}$} & 500 & 1,82 & \multirow{8}{*}{223} & \multirow{4}{*}{2,07} & 1,99 \\
\hline & & 600 & 1,94 & & & 2,11 \\
\hline & & 700 & 2,21 & & & 2,48 \\
\hline & & 800 & 2,31 & & & 2,35 \\
\hline & \multirow{4}{*}{$\begin{array}{c}\text { широкоряд- } \\
\text { ний, } 45 \text { см }\end{array}$} & 500 & 2,16 & & \multirow{4}{*}{2,39} & \\
\hline & & 600 & 2,28 & & & \\
\hline & & 700 & 2,75 & & & \\
\hline & & 800 & 2,38 & & & \\
\hline \multirow{8}{*}{$\begin{array}{c}\text { Скоростиглий } \\
\text { (с. Ворскла) }\end{array}$} & \multirow{4}{*}{$\begin{array}{c}\text { рядковий, } \\
15 \mathrm{~cm}\end{array}$} & 500 & 1,90 & \multirow{8}{*}{228} & \multirow{4}{*}{2,26} & 1,89 \\
\hline & & 600 & 2,28 & & & 2,25 \\
\hline & & 700 & 2,39 & & & 2,52 \\
\hline & & 800 & 2,47 & & & 2,46 \\
\hline & \multirow{4}{*}{$\begin{array}{c}\text { широкоряд- } \\
\text { ний, } 45 \text { см }\end{array}$} & 500 & 1,89 & & \multirow{4}{*}{2,30} & \\
\hline & & 600 & 2,21 & & & \\
\hline & & 700 & 2,65 & & & \\
\hline & & 800 & 2,45 & & & \\
\hline
\end{tabular}

$\mathrm{HIP}_{05, \text { т/га }}$ для фактору: $\mathrm{A}-0,07 ; \mathrm{B}-0,08 ; \mathrm{C}-0,06 ; \mathrm{ABC}-0,10$

Занижені норми висіву сприяли зниженню врожайності насіння до 2,25 т/га - за норми висіву 600 тис./га, до 1,89 т/га - за норми 500 тис./га. Збільшення норми висіву до 800 тис./га не сприяло підвищенню врожайності - 2,46 т/га.

Висновок. Норма висіву більше впливала на величину врожайності сої, ніж спосіб сівби. Сорт Романтика максимальну врожайність мав за норми висіву 700 тис./га - 2,41 т/га. Занижені норми висіву сприяли зниженню врожайності насіння до 2,07 т/га - за норми висіву 600 тис./га та до 1,82 т/га - за норми 500 тис./га. Збільшення норми висіву до 800 тис./га було неефективним 2,39 т/га. У скоростиглого сорту Устя найбільша

\section{БІБЛІОГРАФІЯ}

1. Бабич А. О., Петриченко В.Ф., Адамень $\Phi$.. . Проблема фотосинтезу і біологічної фіксації азоту бобовими культурами // Вісник аграрної науки. - 1996. - №2. - С. 34-39.

2. Бабич А. О. Продуктивний потенціал сортів врожайність була за норми висіву 700 тис./га 2,48 т/га. Занижені норми висіву сприяли зниженню врожайності насіння до 2,11 т/га - за норми висіву 600 тис./га, до 1,99 т/га - за норми 500 тис./га. Збільшення норми висіву до 800 тис./га не сприяло підвищенню врожайності 2,35 т/га.

У загущеному посіві боби формуються у верхній частині рослин. Наслідком цього $є$ низька урожайність насіння. За зрідженого розміщення рослин характерне близьке до поверхні грунту закладання бобів, яке спричиняє значні втрати врожаю під час збирання.

сої для регіонів України // Пропозиція. - 2000. №11. - C. 33-35.

3. Бахмат О. М. Агротехнічне і екологічне обгрунтування сортової технології вирощування сої в умовах південної частини Західного Лісо- 


\section{СІЛЬСЬКЕ ГОСПОДАРСТВО. РОСЛИННИЦТВО}

степу України : автореф. дис...к. с.-г. н. : 06.01.09. - Вінниця, 2005. - 21 с.

4. Марущак П. Г. Удосконалення елементів технології вирощування і використання скоростиглих сортів сої в Правобережному Лісостепу України : автореф. дис... к. с.-г. н. : 06.01.09. Київ, 2005. - 22 с.

5. Петриченко В. Ф., Сологуб О. М. Агроекологічна оцінка сортів сої в умовах північного Лісостепу України // Зб. наук. праць Вінницького ДАУ. - 2002. - Вип. 11. - С. 3-7.

6. Сорти сої Інституту рослинництва ім. В. Я. Юр'єва та технологія вирощування / С. І. Попов, В. О. Матушкін, М. Ф. Божко [та ін.]. - Харків : Магда ЛТД, 2002. - 20 с.

\section{ANNOTATION}

Shevnikov M. Ya., Milenko O. G., Lotysh I. I. The productivity of soy sorts depending on elements of growing technology.

In connection with the intensification of soybean production, there is a question arises of identifying the elements of cultivation technology, which should ensure its high productivity. Among them, the timing, methods and norms of sowing of different soybean varieties are decisive. Further spread of soya in conditions of unstable wetting of the LeftBank part of Forest-Steppe is restrained by the lack of grounded zoning technology for its cultivation, especially in early sowing, where heat is a limiting factor and moisture is sufficient.

The aim of the research was to determine the optimum soybean density by choosing the right seeding and seeding method to ensure optimal plant growth and development and high productivity. In determining the period of sowing, it was taken into account that the early term corresponds to the minimum soil temperature $\left(8-10{ }^{\circ} \mathrm{C}\right)$, during which germination of soybean seeds is possible. The optimal time of sowing was determined when the soil was warmed to $+12-14{ }^{\circ} \mathrm{C}$. The late sowing period corresponded to an increase in the temperature of the soil to $+16-18{ }^{\circ} \mathrm{C}$.

The results of the research showed that the level of soybean yields is largely determined by the change in the feeding area and the way in which
7. Черенков А. В., Артеменко С. Ф., Ільєнко $O$. $B$. Сортова реакція сої різних груп стиглості на способи сівби і норми висіву при різних погодних умовах // Зб. наук. праць Вінницького ДАУ. - 2004. - Вип. 52. - С. 114-116.

8. Шевніков М. Я., Коблай О. О. Застосування біологічних, хімічних та фізичних засобів у технологіях вирощування сої і кукурудзи. - Полтава, 2015. - 258 с. (Монографія).

9. Цехмейструк М. Г., Шелякін В. О., Шевніков М. Я., Литвиненко О. С. Вплив строків сівби на врожайність сортів сої // Вісник Полтавської державної аграрної академії. - 2018. - №1. C. $35-41$.

they are placed in the crop. In this regard, the study of the influence of the size and shape of the feeding area on the competitive interconnections of plants in agrobiocenosis and the individual productivity of plants of soybean varieties is an important scientific problem. The sowing rate was greater than the sowing method, which affected the value of soybean yield. The sort Romantyka had a maximum yield of 700 thousand hectares per hectare -2.41 tons/ha. The low seed rates contributed to a decrease in seed yield to $2.07 \mathrm{t} / \mathrm{ha}$ - under the seed rate of 600 thousand/ha and to 1.82 tons/ha - at the rate of 500 thousand/ha. The increase in the seed rate to 800 thousand/ha was ineffective -2.39 tons/ha. In the fast-growing sort Ustia, the highest yield was 700 tones/ha -2.48 tons/ha. The low seed rates contributed to a decrease in seed yield to $2,11 \mathrm{t} / \mathrm{ha}-$ under the seed rate of 600 thousand/ha, to 1.99 tons/ha - at the rate of 500 thousand/ha. Increasing the seed rate to 800 thousand/ha did not contribute to the increase in yield $-2,35$ tons/ha.

In congested crop, beans are formed in the upper part of plants, resulting in a low seed yield. The fluid distribution of plants is characteristic of the near-surface of the ground for laying beans, which causes significant harvest losses in harvesting.

Keywords: soy, sorts, terms, methods and norms of sowing, productivity. 